EFFICINT

\title{
Analysis of Causes of Centered of Business Location in Unnes Campus Sekaran Area
}

\author{
Aryana Asprilianti Monica ${ }^{凶}$ \\ Jurusan Ekonomi Pembangunan, Fakultas Ekonomi, Universitas Negeri Semarang \\ Permalink/DOI: https://doi.org/10.15294/efficient.vii2.30154
}

Received: January 2018 ; Accepted: March 2018 ; Published: Juny 2018

\begin{abstract}
The purpose of this research is to find out and analyze the factors that can be relied on to predict the cause of concentration of business location in UNNES campus Sekaran area. Population in this research is business actors in UNNES campus Sekaran area 825 with sample 90 responden. Dependent variable in this research is convergence of business location on UNNES campus Sekaran area and independent variables is infrastructure availability, business environment, location cost and revenue. Analysis tool used is Binary Logistic Regression. The result of this research shows that business environment and location cost is reliabel factor to predict cause of concentration of business location on UNNES campus Sekaran area that is Taman Siswa Street. Business environment and location cost variable have same positive probability and can be relied to predict business decision in deciding to be located in Taman Siswa Street. Based on probability calculation through data scenario, probability business actor to be located in Taman Siswa Street will increase with increasing location cost variables and will decrease as the business environment variable increases. Suggestions from this study are that business people should make a business feasibility study before establishing a business in the UNNES area because businesses tend to center on Taman Siswa Street with expensive rental cotss which burdens the initial invesment so that it hampers the business.
\end{abstract}

Keywords: Infrastructure Availability, Business Environment, Location Cost, Binary Logistic Regression

\begin{abstract}
Abstrak
Tujuan penelitian ini adalah untuk mengetahui faktor-faktor yang mempengaruhi penentuan lokasi usaha pada kawasan kampus UNNES Sekaran sehingga cenderung hanya berpusat pada satu kawasan. Populasi dalam penelitian ini adalah para pelaku usaha dikawasan UNNES Sekaran sebanyak 825 dengan sampel 90 responden. Variabel dependen dalam penelitian ini adalah pemusatan lokasi usaha pada kawasan kampus UNNES Sekaran dan variabel independennya adalah ketersediaan infrastruktur, lingkungan bisnis, biaya lokasi dan pendapatan. Alat analisis yang digunakan adalah Binary Logistic Regression. Hasil penelitian ini menunjukkan bahwa variabel lingkungan bisnis dan biaya lokasi merupakan faktor yang berpengaruh untuk memprediksi penyebab pemusatan lokasi usaha pada Jalan Taman Siswa. Variabel lingkungan bisnis dan biaya lokasi sama-sama memiliki probabilitas positif dan dapat diandalkan untuk memprediksi keputusan pelaku usaha dalam memutuskan untuk berlokasi pada Jalan Taman Siswa. Berdasarkan perhitungan peluang melalui skenario data, peluang pelaku usaha untuk berlokasi pada Jalan Taman Siswa akan meningkat seiring dengan meningkatnya variabel biaya lokasi dan akan menurun seiring dengan meningkatnya variabel lingkungan bisnis. Saran dari penelitian ini adalah para pelaku usaha sebaiknya membuat studi kelayakan bisnis sebelum mendirikan usaha di kawasan UNNES Sekaran karena pelaku usaha cenderung berpusat pada Jalan Taman Siswa dengan biaya sewa mahal yang memberatkan biaya awal yang dikeluarkan sehinggga menghambat usaha.
\end{abstract}

Kata Kunci: Ketersediaan Infrastruktur, Lingkungan Bisnis, Biaya Lokasi, Binary Logistic Regression

How to Cite: Monica, A. (2018). Analysis of Causes of Centered of Business Location in Unnes Campus Sekaran Area. EFFICIENT Indonesian Journal of Development Economics, 1(2), $116-125$. https://doi.org/10.15294/efficient.vii2.30154

(C) 2019 Semarang State University. All rights reserved

\footnotetext{
Alamat Korespondensi :

Alamat: Gedung L2 Lantai 2 FE Unnes

Kampus Sekaran, Gunungpati, Semarang, 50229

E-mail : aryana.asprilianti@gmail.com
} 


\section{INTRODUCTION}

Semarang State University, is one of the State Universities in Indonesia. The main campus is located in the Sekaran area (Gunungpati), south of Semarang City, Central Java. And other campuses are located in Ngaliyan (Semarang), Kelud (Semarang), Bendan Ngisor (Semarang), and in Kemandugan, Tegal (Wikipedia). The center of UNNES campus is in the Sekaran area, make the area become a center of economic growth both for the surrounding community and for migrants, because of that the Sekaran area can use the threshold concept, namely the nearest area of goods and services can be offered, and the range of the maximum distance where consumers can access goods and services. In this theory, the business location can be categorized as feasible for business establishment when the area is still within the threshold area and its range, because in the area consumers are considered able to access theirlocation. Therefore, in theory the spread of business within the UNNES campus Sekaran area should spread within the threshold area and its range.

Table 1. Distribution Business Unit of UNNES Campus Sekaran Area

\begin{tabular}{cc}
\hline Location & Unit \\
\hline Banaran Raya St. & 154 \\
Taman Siswa St. & 446 \\
Sekaran Raya St. & 100 \\
Patemon Raya St. & 125 \\
\hline
\end{tabular}

Source :Primary Data, 2018

Became a strategic place in determining business location and business opportunities. Pujiati (2016) stated that development at national and regional levels was carried ot to improving the welfare of the community.

Determination of thebusiness location is explained in theory location which discusses the determination of location for each socioeconomic need. This is based so that the decision in determining business location is not only based on the desire of the business actor, but based on a scientific approach how a place can be categorized in a location that can be considered according to the existing theory.

In the central place theory proposed by Christaller, in determining a business location are four main roads that have a range of $3 \mathrm{~km}$ from the central campus which is used as a business location for business people, namely Banaran Raya Street, Taman Siswa Street, Sekaran Raya Street, and Patemon Raya Street. There are 154 business unit in Banaran Raya Street, 446 business unit in Taman Siswa Street, 100 business unit in Sekaran RayaStreet, and 125 business unit in Patemon Raya Street.

If it is in accordance with Christaller's cental place theory,determination of business location should spread within the threshold areas and its range. However, the results of observations in the field indicate an inequality in determining the location of the business, where the business location is centered on one point, namely Taman Siswa Street.

While the comparison with the second largest number of businesses is on Banaran Raya Street with a difference of 292 business unit or more than twice the number of businesses that exist on Banaran Raya Street. Whereas the other four roads in the area are still cover a range of $3 \mathrm{~km}$ from the center of UNNES Sekaran campus. 
Tabel 2. Total Population in UNNES Campus Sekaran Area

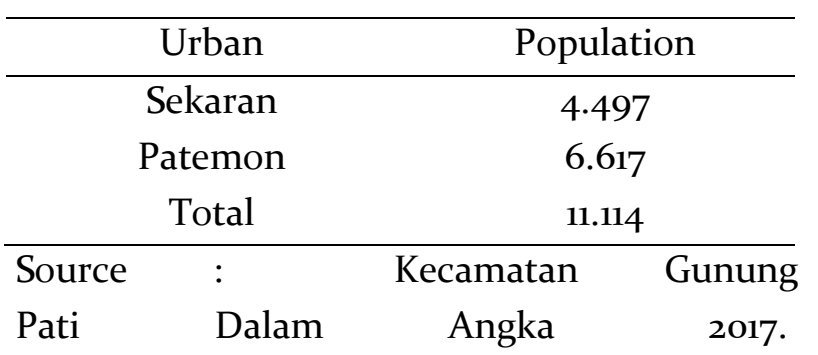

Pujiati (2017) states that on the one side urban areas have very high economic value as a business center. The impact of a city being the center of this business will cause the population to become more densely populated, table 2 below shows the population in 2 urban village in UNNES campus Sekaran area.

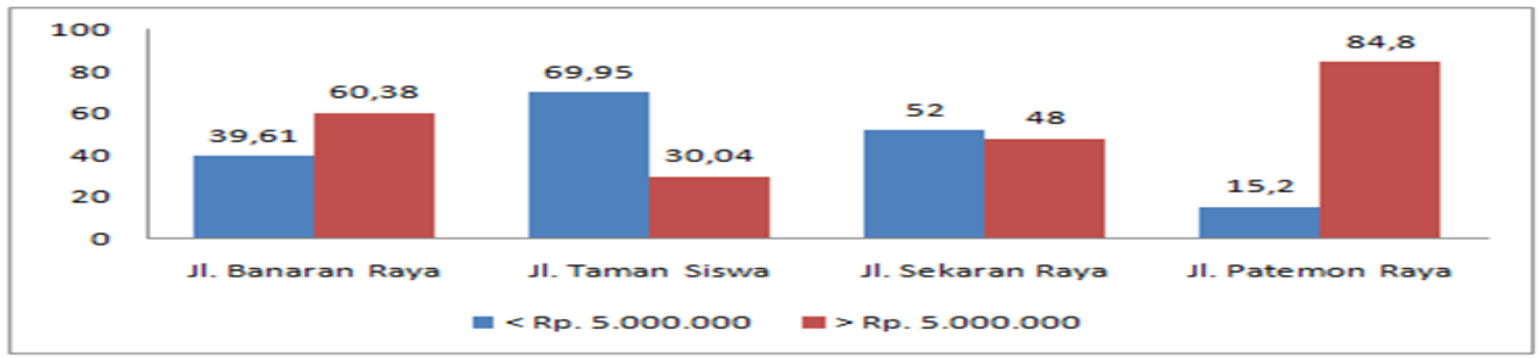

Figure 1. Average Income of Place of Business in UNNES Campus Sekaran Area Source : Primary Data, 2018

From the data on the average amount of income in the 4 area above, Patemon Raya Street is a location with an average income above Rp. 5,000,00o/month at the most, which is 106 or $84.8 \%$ compared to the other three locations, namely Banaran Raya Street as many as 93 or $60.38 \%$, Taman Siswa Street as much as 134 or $30.04 \%$, and Sekaran Raya Street as much as 48 or $48 \%$. Patemon Raya Street is an area that should be most interested in determining the location of the business because with the highest percentage of inco income that is higher than the other three regions.

Based on the data analysis above, the authors propose a research entitled "Analysis of Causes of Convergence of Business Location In Unnes Campus Sekaran Area" and it is hoped that this research can answer what factors can influence the determination of business location and why there is no even distribution, with data and thereality of the distribution of business units in the UNNES Sekaran area.

\section{RESEARCH METHODS}

This research is an explanatory research case study that is research to find out the factors that are taken into consideration by business actors in determining the location of a business. This study tries to explain a subject matter, hypothesis, and analyze the data obtained based on primary data, namely data taken from the questionnaire to respondents, namely business actors in the UNNES Sekaran area.

The population in this study were all business actors within a range of $3 \mathrm{~km}$ from the UNNES campusSekaran, total amount up to 825 business unit (see table 1 ) the sample in this study was selected using random sampling technique. From calculations with the Slovin 
formula found 90 respondents used in this study.

The independent variables in this study are the infrastructure availability, business environment, location costs and revenue. While the dependent variable in this study is the concentration of business locations onTaman Siswa Street.

Method of collecting data in this research is questionnaire method, documentation study and field observation. The questionnaire method was carried out by distributing questionnaires to a number of 90 respondents who had been determined based on previous calculations. Documentation study methods are carried out by reading literature books, journals, magazines, articles, and newspapers that are appropriate to the problem. While the field observation method is carried out by observing the area concerned.

The analytical method used in this study is the logit model (binary logistic regression). Data analysis method using logit is used when the dependent variable (response) is a binary/dichotomous variable. The dichotomy variable usually consists of only two values that represent the occurrence or absence of an event which is usually given a number $o$ and 1. The logit model in the study of the causes ofconcentration of the UNNES Sekaran business location is formulated in the following equation:

$L i=\ln \left(\frac{P i}{1-P i}\right)=\beta 1+\beta 2 K I+\beta 3 L B+\beta 4 B L+$ $\beta 5 P$.

Information :

$L i=\ln \left(\frac{P i}{1-P i}\right):$ Cause of concentration of business locations in the UNNES area $\beta 1$ : $\log$ rasio probability value $\beta 2 K I$ : The slope coefficient variable of infrastructureavailability

$\beta 3 L B$ :The slope coefficient variable of environment variable

$\beta 4 B L$ : The variable coefficient of location costs $\beta 4 P$ : The variable coefficient of revenue

To test the feasibility of the logistic regression model for the data, a number of statistical tests were used, namely goodness of fit, overall model fit test, negalkerke's $\mathrm{R}$ square, and Wald test.

\section{RESULTS AND DISCUSSION}

There are several stages of parameter estimation testing in the logistic regression method. The results of the parameter estimation test are as follows:

\section{Goodness of Fit}

Hosmer and Lemeshow Testconducted to test the suitability of the model (Goodness of Fit) between the results of observations with possible predictions of the model (Hayati, 2002). The results of the test can be seen in Table 2 below:

Table 3. Hosmer and Lemeshow Test

\begin{tabular}{llll}
\hline Step & Chi-square & Df & Sig. \\
\hline 1 & 2.179 & 5 & .824 \\
\hline
\end{tabular}

Source : Primary Data Processed, 2018

Table 3 above show that the value of significant hosmer and lemeshow' sgoodnees of fit test is 0,824 . The value higger than fit test statistic $(0,05)$ which mean hipotesys null be acceptedso that the model is able to predict the value of its observations or it can be said that the model is acceptable because it matches the observational data. 


\section{Overall Model Fit}

Likelihood ratio test used to rate the overall model whether it is fit for data or not. The likelihood ratio test is measured by subtracting the value of -2 log likelihood before the independent variable enters the model with the value of -2 loglikelihood after the independent variable enters the model. The results of the likelihood ratio test can be seen in Table 4 below:

Table 4. Omnibus Tests of Model Coefficients

\begin{tabular}{lllll}
\hline & & $\begin{array}{l}\text { Chi- } \\
\text { square }\end{array}$ & Df & Sig. \\
\hline Step 1 & Step & 42.201 & 4 & .000 \\
& Block & 42.201 & 4 & .000 \\
& Model & 42.201 & 4 & .000 \\
\hline
\end{tabular}

Source : Primary Data Processed, 2018

Based on Table 4, it shows that the chisquare value is 42,201 . The chi-square value of 42,201 was the difference of -2 log likelihood before the independent variable entered the model $(124,366)$ minus -2 log likelihood after the independent variable entered the model $(82,165)$. The chi-square value of 42,201 is greater than the chi-square table on $\mathrm{df} 4$ with a significance level of 0.05 which is 9,488 . Because the chi-square value is calculated $>$ the chi-square table value, then the addition of independent variables will be able to give a real influence on the model or in other words that the model is said to be fit.

\section{Nagelkerke's R Square}

Nagelkerke's $R$ square valuecan be interpreted as $\mathrm{R}^{2}$ values in multiple regression. The value of Nagelkerke's R square processing results with SPSS 16 for Windows can be seen in Table 4 below which shows that the value of Nagelkerke's R Squareis o,50o (50\%). This shows that the independent variables in this study are only able to explain about 50\% of the independent variables while the rest is explained by other variables outside the variables in this study.

Table 5. Model Summary

\begin{tabular}{lllll}
\hline \multirow{2}{*}{ Step } & $\begin{array}{l}-2 \quad \text { Log } \\
\text { Likehood }\end{array}$ & $\begin{array}{l}\text { Cox } \\
\text { Snell } \\
\text { Square }\end{array}$ & $\begin{array}{l}\text { R } \\
\text { R Square } \\
\text { R Sqkerke }\end{array}$ \\
\hline 1 & 82.165 & .374 & .500 \\
\hline
\end{tabular}

Source: Primary data processed, 2018

\section{Wald Test}

This test is used to determine whether the independent variables included in the model have an influence on the dependent variable or not. In addition, it is also used to see how much influence each independent variable has on the dependent variable. The results of the Wald test can be seen in Table 6 below:

Table 6. Variables in the Equation

\begin{tabular}{llll}
\hline Variabel & B. & Sig. & Exp (B) \\
\hline $\mathrm{X}_{1}$ & -.831 & .380 & .436 \\
$\mathrm{X}_{2}$ & 4.112 & .002 & 61.072 \\
$\mathrm{X}_{3}$ & 3.189 & .004 & $\mathbf{2 4 . 2 7 0}$ \\
$\mathrm{X}_{4}$ & -1.045 & .063 & .352 \\
Constant & -5.109 & .001 & .006 \\
\hline
\end{tabular}

Souce: Primary data processed, 2018

Infrastructure availability variable has a coefficient value of -o,831and has a significance level of 0,380 . This shows that the significance value $(0,380)>\operatorname{Pvalue}(\alpha=0,05)$, so it can be interpreted that the infrastructure availability variable is insignificant and cannot be relied upon to predict the cause of business location concentration in the UNNES Sekaran area. 
The business environment variable has a coefficient of 4,112 and has a significance level of 0,002 . This shows that the significance value $(0,002)<$ Pvalue $(\alpha=0,05)$, so it can be interpreted that the business environment variable is significant and can be relied upon to predict the causes of business location concentration in the UNNES Sekaran area.

The location cost variable has a coefficient value of 3,189 and has a significance level of 0,004 . This shows that the significance value $(0,004)<$ Pvalue $(\alpha=0.05)$, so it can be interpreted that the business environment variable is significant and can be relied upon to predict the causes of business location concentration in the UNNES Sekaran area.

Revenue variable has a coefficient value of $-1,045$ and has a significance level of 0,063 . This shows that the significance value $(0,063)>$ Pvalue $(\alpha=0,05)$, so it can be interpreted that the revenue variable is insignificant and cannot be relied upon to predict the cause of business location concentration in the UNNES Sekaran area.

\section{Discussion}

The infrastructureavailability is a variable that cannot be relied on to predict the decision of business actors to be located on Taman Siswa Street, which is the area that becomes the focus of business locations around the UNNES campus, Sekaran. That is, the high and low availability of infrastructure does not have an influence on the decision of the business actor to be located in the Taman Siswa Street area and there is no difference in the opportunity between the decision whether or not the business actor is located in Taman Siswa Street based on the availability of infrastructure.
The negative coefficient sign (-) indicates that there is a negative or unidirectional relationship between the variable infrastructureavailability and the probability of the business actors to want to be located on Taman Siswa Street. This means that if there is a decrease in infrastructure availability, the probability of the business actor to be located on Taman Siswa Street will be higher. Conversely, when there is an increase in infrastructure availability, the probability of business actors to be located on Taman Siswa Street will be lower.

The business environment is a variable that can be relied upon to predict the business actor's decision to be located at Jalan Taman Siswa, which is the area that becomes the focus of business locations around the UNNES campus in Sekaran. This means that there is a difference in opportunities between the decisions of business actors in determining business locations based on business environment variables. The odd ratio value of the business environment variable which can be seen from the $\operatorname{Exp}(\mathrm{B})$ value is 61,072 which means the probability of the respondents who decide to be located at Taman Siswa Street based on the business environment variable 61,072 times greater for the business people who are at Taman Siswa Street compared to the business actors who are not in Taman Siswa Street.

A positive coefficient $(+)$ indicates that there is a positive or direct relationshipbetween the business environment and the probability of a business actor's decision to be located on Jalan Taman Siswa. While the coefficient value of 4.112 means that if there is an increase in the business environment variable of 1 index unit and other 
variables are considered constant then it will cause an increase in the probability of the decision of the business actor to be located at Taman Siswa Street at $\mathbf{4 . 1 1 2} \%$. Conversely, if there is a decrease in the business environment variable of 1 unit of index and other variables are considered constant, it will cause a decrease in the probability of the decision of the business actor to be located on Taman Siswa Street at $4.112 \%$.

Business environment variables such as the distance between the location of the business and the campus, the distance of the location of the business to the boarding house, the distance of the location of the business to another place of business, andbusiness place securityhave a positive effect on the decision of business actors to be located in the Taman Siswa Street area. This means that an area that has a high business environment will increase the decision of business actors to be located in the Taman Siswa Street. Business actors in the Taman Siswa Street try to approach consumers by approaching campus locations and boarding locations which are indicators of business environment variables. The closer the business actor to the business environment, the greater the probability of the decision of the business actor to be located at Taman Siswa Street. Conversely, when business operators are further away from the business environment, it will reduce the probability of the business actor's decision to be located on Taman Siswa Street.

The location cost is a variable that can be relied upon to predict the business actor's decision to be located at Taman Siswa Street, which is the area that becomes the focus of business locations around the UNNES campus in Sekaran. This means that there are differences in opportunities between the decisions of business actors in determining the location of the business based on the variable location costs. The odd ratio value of the location cost variable which can be seen from the $\operatorname{Exp}(\mathrm{B})$ value is $\mathbf{2 4 , 2 7 0}$ which means the probability of the respondents who decide to be located at Taman Siswa Street based on the location cost variable 24,270 times greater for the business people who are at Taman Siswa Street compared to the business actors who are not in Taman Siswa Street.

A positive coefficient $(+)$ indicates that there is a positive or direct relationshipbetween location costs and the probability of a business actor's decision to be located on Taman Siswa Street. While the coefficient value of 3,189 means that if there is an increase in the location cost variable of 1 index unit and other variables are considered constant then it will cause an increase in the probability of the decision of the business actor to be located at Taman Siswa Street at $3,189 \%$. Conversely, if there is a decrease in the location cost variable of 1 index unit and other variables are considered constant, it will cause a decrease in the probability of the decision of the business actor to be located at Jalan Taman Siswa at $3,189 \%$.

The high and low cost of the location has an influence on the decision of the business actor to be located in the Taman Siswa Street. This is because rental prices in the four area are relatively different with the same level of land size. Prices paid by businesses in the Taman Siswa Street area tend to scramble business places, even kiosk / shop owners until they can auction for the highest price rent. 
Based on the conditions in the field, the amount of rental prices that exist causes many new businesses to be easily closed, because the costs incurred when the start of the business is greater and the resulting profits cannot cover the initial costs incurred. This is in accordance with the initial hypothesis and can be explained by Jucius and Terry, the decision model of determining business location selection, the main factor to consider is the cost and expected cost and expected yield in that place (Prasetyo, 2003).

Revenue is a variable that cannot be relied on to predict the decision of business actors to be located on Taman Siswa Street, which is the area that becomes the focus of business locations around the UNNES campus, Sekaran. That is, the high and low availability of revenue does not have an influence on the decision of the business actor to be located in the Taman Siswa Street area and there is no difference in the opportunity between the decision whether or not the business actor is located in Taman Siswa Street based on the availability of infrastructure.

The negative coefficient sign (-) indicates that there is a negative or unidirectional relationship between the variable revenue and the probability of the business actors to want to be located on Taman Siswa Street. This means that if there is a decrease in revenue, the probability of the business actor to be located on Taman Siswa Street will be higher. Conversely, when there is an increase in revenue, the probability of business actors to be located on Taman Siswa Street will be lower.

The results of the above analysis, it can be seen that only business environment andlocation costs variables have an opportunity or probability to predict the causes of business location concentration in the UNNES Sekaran area. These significant variables can be used to create scenarios for each employee's opportunity to decide to be located on Taman Siswa Street or not, the area that is the center of the business location in the UNNES Sekaran area. So from the results of the analysis obtained the logistic regression equation model as follows:

Ln $\left(\frac{p}{1-p}\right)=-5,109+4,112$ Business Environment $+3,189$ Locaton Cost.

Suppose that in scenario 1 the business environment is the closeness to the consumer which is around 200 meters or by $40 \%$ (percentage of 200 meters divided by the farthest distance which is 500 meters) and the location cost is the price of building rent of Rp.10,000,000.0o which is the main consideration as much $36 \%$ (the percentage of the perception of the building rental price is Rp. 10,000,000.00 as the main consideration). The data is used as a basis for calculating the opportunities for each classification, whether or not the business actor is located at Taman SiswaStreet by entering these values into the equation.

In scenario 2 there is an increase in the business environment variables where the closeness to consumers becomes smaller. In scenario 2, the closeness to the consumer is 150 meters or $30 \%$ (a percentage of a distance of 150 meters divided by the farthest distance is 500 meters) while for the location costs with a fixed building rental price of $27 \%$. The existence of these changes will occur differences in opportunities. The reality shows that if there is only an increase in the business 
environment variables and other variables fixed, the chances of the business actor's decision to be located on Taman Siswa Street are dropped or increase to 0,1510 or $15,10 \%$ while the business actor's decision not to be located at Taman Siswa Streethigher to o,8489 or $84,89 \%$.

In scenario 3 there is a change in the location cost variable where the building rental price increases by Rp.2,00o,00o.0o or $20 \%$ (the percentage of the increase in the rental price that has been determined) so that it becomes Rp.12,000,000.00 or $47 \%$ (the amount from $27 \%$ and $20 \%$ ) while the business environment variable with proximity to consumers remains 150 meters or $30 \%$. The increase in location costs, namely the price of the building rent will affect the perception of business actors on the variable location costs as the main consideration or not. From scenario 3 above shows that if there is only an increase in the variable location costs and other variables fixed, then the opportunity for the business actor's decision to be located on Taman Siswa Street will rose to 0,2622 or $26,22 \%$ while the chance of a decision not to be located at Taman Siswa Streetdecrease to 0,7377 or $73,77 \%$.

From the calculations above it can be seen that the probability of a business actors in determining the location of a business on Taman Siswa Street will increase along with the increase in business environment variables and will decrease along with the increase in the location cost variable. Opportunities for business actors located at Taman Siswa Street will be compared when the business environment variable increases greater to the variable location costs. Likewise, various other conditions can be calculated by estimating the logistic regression equation above. With a number of scenarios above it can be useful as a basis for mapping in the future and also as a basis for making decisions orpolicies for the problem of centralizing business locations in the UNNES Sekaran area.

\section{CONCLUSION}

Business environment and location costs variables both have a positive probability and can be relied upon to predict the business actor's decision in deciding to be located on Taman Siswa Street.

Based on data scenarios on business environment and location costs variables it was found that if the criteria for business environment variables getting higher which meant that the distance to the customer was lower, that is $40 \%$ to $30 \%$ while the other variables were constant then the opportunities for business actors located at Taman Siswa Street were lower namely increasing from $17,78 \%$ to $15,10 \%$. Whereas based on the data scenario on the location cost variable it was found that if the criteria for the location cost variable were the building rental price being increased and getting higher to Rp. 11,0oo,ooo, while the other variables were constant it would affect the business actors perception to be located on Taman Siswa Street will be higher from $15,10 \%$ to $26,20 \%$.

\section{REFERENCES}

Aulia, Astri. 2009. Pola Distribusi Spasial Minimarket Di Kota-Kota Kecil. Jurnal Perencanaan Wilayah dan Kota, Vol. 20 No.2, Agustus 2009, hlm. 78 - 94. Bandung.

Hayati, E. 2002. Analisis Regresi Logistik untuk Mengetahui Faktor-faktor yangMempengaruhi 
Frekuensi Kedatangan Pelanggan di Pusat Perbelanjaan "X". Unisla Journal.

Prasetyo, Eko. 2003. Model Keputusan Pemilihan Lokasi Usaha. Jurnal Sains dan Teknologi Sinergi. Yogyakarta : Pusat Penelitian Universitas PGRI.

Pujiati, Amin. 2016. Peluang Kota Menuju Pembangunan Yang Berkelanjutan Dalam Rangka Meningkatkan Kesejahteraan masyarakat. Prosiding Seminar Nasional Multi Disiplin Ilmu \& Call For Papers Unisbank.
2017. Kontribusi Kepemimpinan dan Tata Kelola Kota Terhadap Kota Berkelanjutan. Bingkai Manajemen, 416-429.

Tarigan, Robinson. 2006. Perencanaan Pembangunan Wilayah. Jakarta : Bumi aksara.

Wiki. Universitas Negeri Semarang. Diakses di https://id.wikipedia.org/wiki/Universitas_Negeri_ Semarang tanggal 21 Februari 2018 pukul 22.26 